International Research Journal of Management, IT \& Social Sciences
Available online at https://sloap.org/journals/index.php/irjmis/
Vol. 7 No. 3, May 2020, pages: 58-64
ISSN: 2395-7492
https://doi.org/10.21744/irjmis.v7n3.898

\title{
Digital marketing strategy on travel tourism businesses in marketing
} 4.0 era

Ni Putu Rekha Chandra Dewi ${ }^{\text {a }}$

Article history:

Submitted: 18 January 2020

Revised: 09 February 2020

Accepted: 27 March 2020

\section{Keywords:}

industry 4.0;

marketing 4.0;

marketing strategy;

transportation system;

travel agent;

\begin{abstract}
An online-based transportation system has been created thanks to the industrial revolution 4.0, indirectly this system will slowly begin to shift transportation services such as travel that still uses conventional marketing systems. Social media is a media platform that focuses on the existence of users who facilitate them in their activities and collaborations. So in this case, the media can be seen as a virtual medium that strengthens between users as well as a social bond. According to social media is the media used by consumers to share text, images, sound, and video information both with others and companies and vice versa. With these unique characteristics, social media can be used as an effective business promotion tool. Wonderfull Bali is a company engaged in the field of travel tourism. In addition to travel tours, Wonderfull Bali also caters for events, car and motorbike rentals, spas \& massages, shops, yoga, beauty, and skincare. The travel agent industry is no longer able to rely on walk-in service for ticket reservations and choosing travel packages, everything has changed with digital. Go-Digital is one of the Ministry of Tourism's strategic programs to win the market in the industrial era 4.0 to reach the target of 20 million foreign tourists in 2019. This research is expected to contribute to corporate leaders and marketing managers to make policies in determining marketing strategies based on results from the phenomenon under study.
\end{abstract}

International research journal of management, IT and social sciences (C) 2020. This is an open access article under the CC BY-NC-ND license (https://creativecommons.org/licenses/by-nc-nd/4.0/).

Corresponding author:

Ni Putu Rekha Chandra Dewi,

Undiknas Graduate School Master of Management Study Program, Denpasar, Indonesia.

Email address: puturekhachandra@gmail.com

Undiknas Graduate School Master of Management Study Program, Denpasar, Indonesia 


\section{Introduction}

E-marketing describes the company's efforts to inform, communicate, promote, and market products and services via the internet (Kotler \& Armstrong, 2004). E-marketing is part of e-commerce, which means marketing products and services using the internet. By utilizing e-marketing, it can help companies to facilitate in terms of introducing or marketing the products produced.

E-marketing is the answer to the problems experienced by new business owners because they want to minimize costs incurred to promote products or services being marketed. If previously the company had to spend a lot of money to market a product or service such as making brochures, paying handsomely to advertise their products in the newspaper or paying rent to open a place of business, now by utilizing e-marketing the company can benefit because it can be done anytime and anywhere only by utilizing the internet.

E-marketing can facilitate a company starting from marketing its products, can cover consumers widely, and can interact directly with consumers through chat. Because of the relationship between producers and consumers also has an impact on the revenue generated by the company. If the company can establish good relations with consumers, consumers will be loyal to the company. In the world of marketing, this is called relationship marketing. Relationship marketing is a marketing concept that emphasizes maintaining relationships between consumers and companies through effective communication between companies and consumers (Haryanto, 2014).

The most-loved social media application by millennials is Instagram. This, too, because Instagram is an application that has full features. Instagram not only provides a personal account but also provides a business account intended for people who use Instagram to develop their business, both to peddle their products or to interact with consumers. In the Instagram application, users can also upload photos and videos that can attract potential customers to approach their Instagram page. However, before Instagram appeared, Facebook first became a social media that was loved. The same thing with Instagram, Facebook can also be used by users to share their photos or videos. In using Facebook, users can also make a status that later, other users will give likes or comments.

In addition to Instagram, companies can also create applications that can be uploaded by consumers. Thus, consumers can easily get information about what products or services offered by the company. The company that can be used as an example here is Go-Jek., A company that has succeeded in creating applications that consumers can upload via smartphones. There are many features contained in this application, so consumers can be spoiled with features that are available according to their needs.

According to Van Dijk, as quoted by Nasrullah (2015), social media is a media platform that focuses on the existence of users who facilitate them in their activities and collaborations. So, in this case, the media can be seen as a virtual medium that strengthens between users as well as a social bond. Social media, according to Kotler (2011), is the media used by consumers to share text, images, sound, and video information both with others and companies and vice versa. With these unique characteristics, social media can be used as an effective business promotion tool.

An online-based transportation system has been created thanks to the industrial revolution 4.0, and indirectly this system will slowly begin to shift transportation services such as travel that still uses conventional marketing systems. Go-Jek and Grab are examples of successful transportation technology advancements in this era. They can create various features ranging from ordering food online, providing beauty services, shopping for home needs to being able to take consumers to their desired destinations. Consumers can also see the whereabouts of the online driver through the available features that are already connected with google map (Alamdari, 2002; Castillo-Manzano \& LópezValpuesta, 2010; Bennett, 1993).

\section{Literature review}

\section{Marketing 4.0}

The birth of the 4.0 revolution was marked by the integration of technology as the cause of bias between physical, digital, and biological fields (Schwab in Lee et al., 2018). Schwab identifies these three things as changing megatrends in the industrial revolution 4.0 (Schwab, 2016; Utomo \& Darma, 2020; Witkowski, 2017; Lee et al., 2015; Stock \& Seliger, 2016).

Marketing 4.0 is a marketing approach that combines online and offline interactions between companies and consumers, combining style with substance in forming a brand that will ultimately complement the machine to machine relationship with a touch between people to increase customer engagement.

Dewi, N. P. R. C. (2020). Digital marketing strategy on travel tourism businesses in marketing 4.0 era. International Research Journal of Management, IT and Social Sciences, 7(3), 58-64. https://doi.org/10.21744/irjmis.v7n3.898 
Dholakia et al., (2010) states: "Marketing 4.0's ability can lead the system to be more superior in keeping up with the increasing market turmoil. Customers are placed in a new digital era, thus fueling customer interactions with products".

4.0 capabilities make the system superior in countering the ever-increasing market turmoil. Consumers are placed in a new digital era, thus allowing customers to interact directly with the product.

\section{Materials and Methods}

\section{Location}

This study chose Wonderfull Bali as the object of research. In addition to travel tours, Wonderfull Bali also caters for events, car and motorbike rentals, spas \& massages, shops, yoga, beauty, and skincare. The travel agent industry is no longer able to rely on walk-in service for ticket reservations and choosing travel packages, and everything has changed with digital. Go-Digital is one of the Ministry of Tourism's strategic programs to win the market in the industrial era 4.0 to reach the target of 20 million foreign tourists in 2019 . Tourism 4.0 will target the millennial generation target, which currently reaches 50 percent of the total inbound tourists to Indonesia. Arief Yahya, as Minister of Tourism, said, "The more digital, the more professional. The more digital, the more global. So whoever controls the community of young people, it is he who has the potential to win the future market or winning the future market."

\section{Data analysis technique}

The data analysis of this research is a qualitative descriptive analysis, meaning that the researcher in analyzing the data will observe, understand, and interpret any data or facts obtained from interviews and observations and studies arranged into the text that has been analyzed through interpretation to obtain meaning. Activities in the qualitative analysis are carried out interactively and continue continuously until the data is complete. Qualitative data analysis can be described as follows.

\section{Results and Discussions}

\section{Digital Marketing Strategies on Products}

Before the company determines the strategy to be used, of course, the company must create a product that will be used by consumers according to their needs. Products are not only in the form of goods, but services can also be referred to as products in the company. Awareness of Wonderfull Bali with consumer needs for services in the world of tourism has made Wonderfull Bali provide several services that can be used by consumers. The informants interviewed by researchers have used different services from Wonderfull Bali. Ratih Delima uses ticket booking services for Wake Bali Dolphin, and Ayu Sri Adnyani orders tickets for rafting, then Cok Bintari and Mia can order spa services from Wonderfull Bali. This proves that Wonderfull Bali has its strategy in providing a variety of products to be marketed to consumers. In line with research conducted by Hilmi (2019), at PT. The nuances of Prima Nusantara Tour \& Travel Jember, which refers to the marketing mix strategy can be explained that the product is one of the important elements in the marketing mix because the product will be the determining variable in business activities.

\section{Digital Marketing Strategies on Price}

Price is the main key for consumers to buy goods in marketing, price is a measure expressed in terms of money where consumers can obtain goods or services after the consumer is willing to release a certain amount of money. Pricing can be a strength to compete in the market. The Appstore application of Wonderfull Bali has listed prices that can be directly seen by consumers. In determining prices, Wonderfull Bali has conducted price monitoring before setting prices to be affordable for consumers. Mia, Ayu Sri Adnyani, and Cok Bintari have the same opinion that the price offered is very affordable. Wonderfull Bali has also provided discounted prices that can attract consumers' interest in deciding to use the services offered, as said by informant Ratih Delima who was interested in the price discount given by Wonderfull Bali. Researchers can conclude that Wonderfull Bali has succeeded in pricing strategies to attract consumer interest. 
Digital Marketing Strategies on Promotion

All informants who are consumers of Wonderfull Bali agree that they know that Wonderfull Bali through Instagram social media, namely @wonderfullbaliofficial and applications that can be uploaded on the Appstore and Playstore. This is a promotional strategy chosen by business owners to be able to reach consumers widely. The use of digital media as a forum to promote products has been carried out by almost all business operators, especially in the field of tourism services.

\section{Digital Marketing Strategies on Place}

Places related to product access and distribution. Location becomes an important role in marketing because it is related to after-sales satisfaction and before-sales customer satisfaction. In the progress of digital technology that is happening right now, the place in marketing has shifted to utilizing technology, what is meant here is an online marketplace where sellers and buyers make transactions using internet media. In online marketplaces, consumers can process communication and bargaining with sellers as well as in conventional markets. Online marketplaces can reduce operating costs, marketing a wider range of products, and increase profits from businesses. In determining the right place to be able to reach the broad market, naturally, Wonderfull Bali has chosen the online marketplace. From the beginning, the consumer gets information until the consumer decides to buy the product; all is done online. Consumers also feel comfortable with this strategy. This was conveyed by all informants, one of whom was Cok Bintari, who said that with the application created by Wonderfull Bali, consumers could feel time efficient, comfortable, and feel a sense of trust.

\section{Digital Marketing Strategies in People}

All the attitudes of employees or people who are in a company influence consumer perceptions of success in the delivery of services (service encounter). A good employee attitude in a company is an added value in the eyes of consumers. According to Zeithaml and Bitner, cited by Ratih Hurriyanti (2005), people are all actors who play a role in the presentation of services so that it affects the perception of buyers. Wonderfull Bali has succeeded in providing good service to every customer. This was conveyed by all informants, one of whom was Ayu Sri Adnyani, who was satisfied with the services provided by the Wonderfull Bali by replying to the chat quickly and answering consumer questions in a friendly manner.

\section{Digital Marketing Strategies on Process}

Alma \& Hurriyati (2008), explained that the process of service is a major factor in the service marketing mix as service customers will often feel the service delivery system as part of the service itself. Besides this, the decision in operations management is very important for the success of service marketing. This means that certain companies must have their way of serving their customers. After consumers search for information and decide to buy products or services, it will continue at the process stage, how companies serve customers with a fast process. A fast and transparent process strategy is carried out by the company so that consumers are not disappointed with the services provided. Informant Cok Bintari said that he felt the process that occurred when using the services of Wonderfull Bali was fairly fast because using the Appstore that was uploaded on a smartphone so that the process became faster after making payments for the service can already be used. Ayu Sri Adnyani also conveyed the same. However, with a different application, namely Instagram @ wonderfullbaliofficial Ayu Sri Adnyani, also got a fast process starting from the beginning of searching for information to finally using the services of Wonderfull Bali.

\section{Digital Marketing Strategies on Physical Evidence}

Physical evidence is the environment, color, layout, logos, and additional facilities. This is related to the appearance of a product/service offered. It is related to the packaging presented to attract consumer interest. Physical evidence of a company or brand in the form of a logo or packaging must be made interestingly because the first thing that consumers pay attention to before buying a product or service is the outside appearance, whether attractive or boring. This is a challenge for the company so as not to lose competitiveness with other competitors by choosing the use of colors and designs. In the application display from Wonderfull Bali, it appears that the company is thinking of ways to obtain a

Dewi, N. P. R. C. (2020). Digital marketing strategy on travel tourism businesses in marketing 4.0 era. International Research Journal of Management, IT and Social Sciences, 7(3), 58-64. https://doi.org/10.21744/irjmis.v7n3.898 
display that attracts consumers. This is evident from the statement of the interested informant because the appearance of the application and uploads from Wonderfull Bali is quite interesting. According to Cok Bintari, what made him interested was the appearance of the colored application and added a variety of features.

\section{Digital Marketing Strategy on Power}

Power (power) is the effort made to take advantage of opportunities arising from the regulations regarding the business carried out. Recognize, foster relationships with parties who influence the market. The company certainly needs to foster relationships with parties who influence the market, so that this becomes the company's strength in building its business (Kumar et al., 2012; Slater et al., 2010; Kirtiş \& Karahan, 2011; Ulaga \& Chacour, 2001). Wonderfull Bali itself has collaborated with the Provincial Government (provincial government) of Bali by using the calendar of tourism events in the provincial government of Bali. Besides that, Wonderfull Bali has also collaborated with @infodenpasar by uploading information about the services offered by Wonderfull Bali. @infodenpasar is an Instagram account that often uploads important information and events that occur in Bali, precisely in the city of Denpasar. Info Denpasar itself has as many as 860,000 followers, which, of course, is the right place for business owners to market their business. Informants interviewed by researchers, namely Mia and Ayu Sri Adnyani, stated that the strength possessed by Wonderfull Bali lies in the way in working with Instagram @ infodenpasar accounts so that it can be known to the wider community.

\section{Digital Marketing Strategies on Public Relations}

Public relations are the art of creating better public understanding so that it can deepen public trust in an individual or organization. Thinking about and creating various approaches to be able to build a good image of the product or service among the community. After the company has succeeded in attracting consumers' interest in its products, the company must create various approaches to be able to build a good image of the products and services among the public. The company has its strategy in building a good image in the eyes of consumers, such as the results of interviews of researchers with informants who are business owners of Wonderfull Bali that to get good value in the eyes of consumers the company does a variety of ways one of them by providing fast and friendly service to create a good relationship between producers and consumers. Consumers will provide value to the company after they use the services of the company. Evaluation of informants interviewed by researchers about Wonderfull Bali as a whole gave a good grade. According to the informants of marketing and service strategies in providing information by Wonderfull Bali, it is appropriate, even Mia's informants said that they would promote Wonderfull Bali to those closest to them because of the experience when shopping was satisfying.

\section{Conclusion}

This research is expected to have a contribution to company leaders and marketing managers to make policies in determining marketing strategies based on the results of the phenomenon under study. The Wonderfull Bali digital marketing strategy seen from the product has been able to attract consumers' interest because there are a variety of products offered so that consumers can choose according to their needs. Wonderful Bali's digital marketing strategy seen from price has been able to make consumers decide to buy products in the form of services that are marketed, this is because the pricing strategy carried out by Wonderfull Bali provides affordable prices for consumers. The Wonderfull Bali digital marketing strategy seen from the promotion has been able to make consumers know information about Wonderfull Bali, both the information on the products being sold and the prices offered. Wonderful Bali's digital marketing strategy seen from a place has been able to make consumers comfortable shopping at the online marketplace created by Wonderfull Bali, such as creating applications that can be uploaded via the Appstore and Playstore on smartphones. Wonderful Bali's digital marketing strategy seen from people has been able to make consumers feel satisfied with the services provided. The Wonderfull Bali digital marketing strategy seen from the process has been able to make consumers feel satisfied with the speed of the process from the initial order to the service is used. Wonderful Bali's digital marketing strategy, seen from physical evidence, has been able to attract consumers' interest to visit social media and applications owned by Wonderfull Bali, this is caused by the appearance of attractive social media and applications. Wonderfull Bali digital marketing strategy seen from the power has been able to make consumers decide to use the services of Wonderfull Bali because of the power in determining the right marketing 
strategy by establishing good relations with parties who have a major influence on the market. Wonderful Bali's digital marketing strategy seen from public relations has succeeded in making consumers give a good image to the company because this company can establish good communication with consumers.

\section{Conflict of interest statement}

The authors declared that they have no competing interests.

\section{Statement of authorship}

The authors have a responsibility for the conception and design of the study. The authors have approved the final article.

Acknowledgments

We are grateful to two anonymous reviewers for their valuable comments on the earlier version of this paper.

Dewi, N. P. R. C. (2020). Digital marketing strategy on travel tourism businesses in marketing 4.0 era. International Research Journal of Management, IT and Social Sciences, 7(3), 58-64. https://doi.org/10.21744/irjmis.v7n3.898 


\section{References}

Alamdari, F. (2002). Regional development in airlines and travel agents relationship. Journal of Air Transport Management, 8(5), 339-348. https://doi.org/10.1016/S0969-6997(02)00014-5

Alma, B., \& Hurriyati, R. (2008). Manajemen corporate \& strategi pemasaran jasa pendidikan. Alfabeta.

Bennett, M. M. (1993). Information technology and travel agency: A customer service perspective. Tourism Management, 14(4), 259-266. https://doi.org/10.1016/0261-5177(93)90060-X

Castillo-Manzano, J. I., \& López-Valpuesta, L. (2010). The decline of the traditional travel agent model. Transportation Research Part E: Logistics and Transportation Review, 46(5), 639-649. https://doi.org/10.1016/j.tre.2009.12.009

Dholakia, N., Zwick, D., \& Denegri-Knott, J. (2010). Technology, consumers, and marketing theory. Marketing Theory, 1 .

Haryanto, B. (2014). The influence of ecological knowledge and product attributes in forming attitude and intention to buy green product. International Journal of Marketing Studies, 6(2), 83.

Hilmi, M. (2019). Green food value chain development: Learning from the bottom of the pyramid. Middle East J, 8(2), $542-560$

Hurriyati, R. (2005). Bauran pemasaran \& loyalitas konsumen. Bandung: Alfabeta.

Kirtiş, A. K., \& Karahan, F. (2011). To be or not to be in social media arena as the most cost-efficient marketing strategy after the global recession. Procedia-Social and Behavioral Sciences, 24, 260-268. https://doi.org/10.1016/j.sbspro.2011.09.083

Kotler, P. (2011). Reinventing marketing to manage the environmental imperative. Journal of Marketing, 75(4), 132135.

Kotler, P., \& Armstrong, G. (2004). Prinsip-Prinsip Pemasaran, diterjemahkan oleh Bob Sabran.

Kumar, V., Rahman, Z., Kazmi, A. A., \& Goyal, P. (2012). Evolution of sustainability as marketing strategy: Beginning of new era. Procedia-Social and Behavioral Sciences, 37, $482-489$. https://doi.org/10.1016/j.sbspro.2012.03.313

Lee, J., Bagheri, B., \& Kao, H. A. (2015). A cyber-physical systems architecture for industry 4.0-based manufacturing systems. Manufacturing letters, 3, 18-23. https://doi.org/10.1016/j.mfglet.2014.12.001

Lee, M. I., Tsai, A. Y., Nazar, S. N., \& Koo, C. (2018). U.S. Patent No. 9,918,240. Washington, DC: U.S. Patent and Trademark Office.

Nasrullah, R. (2015). Media Sosial: Prosedur, Tren, dan Etika. Bandung: Sembiosa Rekatama Media.

Schwab, K. (2016). "Summary for policymakers." Climate Change 2013: The Physical Science Basis: 1-30.

Slater, S. F., Hult, G. T. M., \& Olson, E. M. (2010). Factors influencing the relative importance of marketing strategy creativity and marketing strategy implementation effectiveness. Industrial Marketing Management, 39(4), 551559. https://doi.org/10.1016/j.indmarman.2008.03.007

Stock, T., \& Seliger, G. (2016). Opportunities of sustainable manufacturing in industry 4.0. Procedia Cirp, 40, 536541. https://doi.org/10.1016/j.procir.2016.01.129

Ulaga, W., \& Chacour, S. (2001). Measuring customer-perceived value in business markets: a prerequisite for marketing strategy development and implementation. Industrial marketing management, 30(6), 525-540. https://doi.org/10.1016/S0019-8501(99)00122-4

Utomo, I. G. W., \& Darma, G. S. (2020). Measuring optimization of digital military programs: an innovation of information and communication systems in industrial digitalization 4.0. International Research Journal of Engineering, IT \& Scientific Research, 6(2), 39-46. https://doi.org/10.21744/irjeis.v6n2.862

Witkowski, K. (2017). Internet of things, big data, industry 4.0-innovative solutions in logistics and supply chains management. Procedia engineering, 182, 763-769. https://doi.org/10.1016/j.proeng.2017.03.197 